\title{
Production of Antileukemic Enzyme L-asparaginase from Marine Bacteria Associated with Coral Siderastrea stellate (Verrill, 1868), Brazil
}

\author{
${ }^{1}$ Bruno Oliveira de Veras, ${ }^{2}$ Yago Queiroz dos Santos, ${ }^{3}$ Alexandre Gomes da Silva, ${ }^{4}$ Fernanda Granja da Silva Oliveira, \\ ${ }^{5}$ Krystyna Gorlach-Lira, ${ }^{6}$ Raphael de Oliveira Nascimento Lacerda, ${ }^{7}$ Jackson Roberto Guedes da Silva Almeida, ${ }^{8}$ Elizeu \\ Antunes dos Santos and ${ }^{9}$ Márcia Vanusa da Silva.
}

${ }^{1}$ Department of Antibiotics, Federal University of Pernambuco, Brazil

${ }^{2}$ Department of Biochemistry, Federal University of Rio Grande do Norte, Brazil

${ }^{3}$ Department of Antibiotics, Federal University of Pernambuco, Brazil

${ }^{4}$ Center of Studies and Research of Medicinal Plants (NEPLAME), Federal University of São Francisco Valley, Brazil

${ }^{5}$ Department of Molecular and Cellular Biology, Federal University of Paraiba, Brazil

${ }^{6}$ Department of Dentistry, State University of Paraiba, Brazil

${ }^{7}$ Center of Studies and Research of Medicinal Plants (NEPLAME), Federal University of São Francisco Valley, Brazil

${ }^{8}$ Department of Biochemistry, Federal University of Rio Grande do Norte, Brazil

${ }^{9}$ Department of Biochemistry, Federal University of Pernambuco, Brazil

Correspondence Author: Bruno Oliveira de Veras, Department of Antibiotics, Federal University of Pernambuco, Brazil; E-mail:Bruno.overas@ufpe.br

Received date: 12 August 2018, Accepted date: 15 November 2018, Online date: 27 November 2018

Copyright: $\odot 2018$ Bruno Oliveira de Veras, et al, This is an open-access article distributed under the terms of the Creative Commons Attribution License, which permits unrestricted use, distribution, and reproduction in any medium, provided the original author and source are credited.

\begin{abstract}
L-asparaginase, an antileukemic drughas been approved for clinical use for many years in the treatment of childhood Acute Lymphoblastic Leukaemia (ALL), is obtained originally from bacteria Escherichia coli and Erwinia carotovora. The LAsparaginase (LA) is an enzyme capable of selective hydrolysing of the amino acid L-asparagine (E.C. 3.5.1.1.), it presents several technological applications. L-asparaginase from bacteria can cause anaphylaxis and other abnormal sensitive reactions due to the low specificity of the enzyme. Toxicity and repression caused by bacterial L-asparaginase has intensified new research aimed to obtain bacterial strains producing this enzymatic type with a more effective enzyme without adverse reactions. In the present study, L-asparaginase producing bacteria were isolated from colonies of Siderastrea stellata (Verrill, 1868) Cnidaria, Scleractinia. Sixty-nine bacterial strains were tested for L-asparaginase production using a fast plaque technique, in which six were positive in screening for L-asparaginase. Positive isolates in qualitative screening demonstrated capacity to produce halotolerant and thermostable L-asparaginase, presenting growth and enzymatic production in medium containing $1.0 \mathrm{M} \mathrm{NaCl}$. The isolates showed total enzymatic activity varying from 170.0 to $300.5 \mathrm{IU} / \mathrm{mL}$. The producers were identified as Bacillus subtilis based on morphological and molecular characteristics of the $16 S$ rRNA gene. It was found that they have the ability to secrete this enzyme in the extracellular environment. These isolates presents an enormous potential for application in several areas of biotechnology.
\end{abstract}

Key words: bacteria, L-asparaginase, antileukemic, enzyme, potential.

\section{INTRODUCTION}

Covering more than $75 \%$ of the Earth's surface, the marine environment is a rich source of biological and chemical diversity, containing endless habitats that may present adverse survival conditions. However, these conditions may favour the establishment of microorganisms with promising characteristics on the prospecting of enzymes that have extraordinary properties (Hu et al., 2015; Dumorne et al., 2017; Izadpanah Qeshmi et al., 2018). The use of enzymes in the treatment of malignant tumors has driven great interest on replacing conventional chemotherapy, through the capacity of tumor suppression by nutritional deficiency duethe enzymatic catalytic action, being a promising approach due to the high specificity in detriment to the conventional chemotherapeutic agents (Cocco et al., 2011; Hensley et al., 2013).

The enzyme L-Asparaginase (LA), catalyzes the hydrolysis of the amino acid L-asparagine (Asn) in L-aspartic acid (Asp) and ammonia (EC 3.5.1.1), and can be produced by various organisms such as plants, bacteria and fungi (Michalska and Jaskolski, 2006; Srivastava et al., 2018). The enzyme produced by bacteria can be found in two subtypes depending on the microbial species. The subtype I is found in the cytoplasm acting on amino acid metabolism and exhibiting a high Michaelis constant $(\mathrm{Km})$ due to its low specificity for the substrate, while subtype II is found in the periplasmic or extracellular region and plays an important role in the nitrogen cycle, presenting a low Km value, indicating a high substrate specificity (Campbell et al., 1967; Wriston and Yellin, 1973).

The FDA and WHO organizations have approved L-asparaginase for the effective treatment of Acute Lymphoblastic Leukaemia (ALL), Myelomonocytic Leukaemia (AML), Hodgkin's disease, lymphosarcoma treatment, reticulosarboma and melanosarcoma (Chen et al., 2014; Shrivastava et al., 2015). Among the several types of leukemia that have the greatest use of L-asparaginase is Acute Lymphoblastic Leukemia (ALL), which has nutritional enhancement of tumor cells, where the leukemic cells present a serious need for exogenous supplementation of the amino acid asparagine due to the depletion of the activity Asparagine 
Citation: Bruno Oliveira de Veras, et al., Production of Antileukemic Enzyme L-asparaginase from Marine Bacteria Associated with Coral Siderastrea stellate (Verrill, 1868), Brazil, Australian Journal of Basic and Applied Sciences. 12(11): 87-91. DOI: 10.22587/ajbas.2018.12.11.8

Synthase. Given the high requirement of this amino acid, deprivation results in inhibition of protein synthesis and subsequent death of tumor cells (Gallagher et al., 1989; Narta et al., 2007).

Clinical trials indicate that the treatment of Acute Lymphoblastic Leukaemia (ALL) using LA causes complete remission of tumour cells in more than $90 \%$ of the affected children by neoplasia within 4 weeks, a major advance in modern oncology (Cocco et al., 2011; Shrivastava et al., 2015). Despite the enormous importance of LA in antineoplastic therapy, there are few microorganisms used in the production of the enzyme, the forms coming from Escherichia coli and Erwinia carotovora (Narta et al., 2007). Several reports of undesirable side effects of the drug from these microorganisms, such as the development of diabetes, dysfunction of liver and pancreas, skin rashes, fever, leukopenia, neurological seizures, mild allergic reactions, anaphylaxis, haemorrhage (Mahajan et al., 2014; Alqasim et al., 2018).

To overcome the negative side effects of LA using the enzyme that shows toxicity and immunosuppression, new research is being carried out in the hope of finding new enzymes with new and differentiated biochemical propertiesfor application in antitumor therapy. Among the infinite environments and LA producing microorganisms, bacteria of marine origin have demonstrated great production capacity with great potential of application with new chemical structures, high specificity, low molecular weight and low toxicity (Prihanto et al., 2016; Prabhu et al., 2017; Lee et al., 2018)

This study aimed to evaluate the production capacity of L-asparaginase and to identify coral symbiotic bacteria from Siderastrea stellata (Verrill, 1868) in a Brazilian coral reefs ecosystem $7^{\circ} 08^{\prime} 50^{\prime \prime} \mathrm{S} ; 34^{\circ} 47^{\prime} 51^{\prime \prime} \mathrm{W}$.

\section{MATERIALS AND METHODS}

\section{Isolation of bacteria}

The bacterial strains were aseptically obtained from collected tissues of Siderastrea stellata Verrill, 1868 (Cnidaria, Scleractinia) colonies at Cabo Branco coral reefs, Paraiba State, Brazil ( $\left.7^{\circ} 08^{\prime} 50^{\prime \prime} \mathrm{S} ; 3^{\circ} 47^{\prime} 51^{\prime \prime} \mathrm{W}\right)$. For bacterial isolation from the anthozoan, samples were suspended in sterile saline solution, agitated until homogenization was achieved and then spread over marine agar plates ( $\mathrm{pH} 8.0 \pm 0.3$ ) containing $5 \mathrm{~g} / \mathrm{l}$ peptone; $1 \mathrm{~g} / \mathrm{l}$ yeast extract; $15 \mathrm{~g} / \mathrm{l}$ agar diluted in sterile marine water and incubated at $55^{\circ} \mathrm{C}$ until adequate growth was achieved (Dustan, 1973).

\section{Bacterial identification}

To identify the L-asparaginase-producing isolates, morphophysiological and molecular data were evaluated (Hogg, 1999). The sequence of gene 16S rRNA was amplified from extracted DNA. Bacterial universal primers 26F (5'- GAGTTTGATCMTGGCTCAG- 3') and 1492R (5' -ACGGCTACCTTGTTACGACTT$3^{\prime}$ ') were used to amplify the 16S rDNA gene by Polymerase Chain Reaction (PCR) performed in MWG-Biotech Primus 96 Plus Thermal Cycler (Primus, USA). Each reaction mixture $(50 \mu \mathrm{L})$ contained reaction buffer, $2 \mathrm{mM} \mathrm{MgCl}_{2}, 0.2 \mu \mathrm{M}$ of each primer, $0.2 \mathrm{mM}$ of dNTPs, $1 \mathrm{U}$ of DNA polymerase and 40 ng of genomic DNA. The amplification products were directly purified from the PCR reaction using the Wizard® SV Genomic DNA Purification System. The obtained 16S rRNA gene was sequenced by ATCGene (UFRGS, Porto Alegre, RS, Brazil) using the automated sequencer ABI-PRISM 3100 Genetic Analyzer. The isolated sequence was compared to sequences deposited in the Genbank database (NCBI). For the local alignment, the BLASTn tool (NCBI) was used. The MEGA 6.0 software was used for monitoring multiple sequences and for construction of a dendrogram by the Neighbor-Joining method.

\section{Screening of L-asparaginase producing bacteria}

The detection of LA- producing bacteria was performed according to the modified methodology of Mahajan et al. (2013), using the Czapek Dox agar medium having the following composition: $\mathrm{Na}_{2} \mathrm{HPO}_{4}-6,0 \mathrm{~g} / 1 ; \mathrm{KH}_{2} \mathrm{PO}_{4}-2,0 \mathrm{~g} / 1 ; \mathrm{L}-$ asparagine - 10,0 g / 1; Glycerol - 2,0 g /l; $\mathrm{MgSO}_{4}-7 \mathrm{H}_{2} \mathrm{O}-0,5 \mathrm{~g} / 1 ; \mathrm{CaCl}_{2}-$ $2 \mathrm{H}_{2} \mathrm{O}-0,005 \mathrm{~g} / 1$; Agar-20,0 g / 1, at different $\mathrm{pHs}(4.5,5.5,6.5,7.5)$. The media was supplemented separately with the indicators Bromocresol Green, Bromothymol Blue, Phenol Red, Bromocresol Purple, Neutral Red. Plates with the bacterial cultures were incubated at $55^{\circ} \mathrm{C}$ for 48 hours, with the positive result of forming a halo around the colonies.

The positive isolates in the screening were evaluated for the capacity of producing halotolerant L-asparaginase, being the isolates grown in medium Czapek Dox agar medium with the red phenol indicator, in increasing $\mathrm{NaCl}$ molarities $(0,0.25,0.50,1.0,1.25$ and $1.5 \mathrm{M})$.

\section{Enzymatic Production}

The isolates were grown in Czapek Dox $\left(\mathrm{Na}_{2} \mathrm{HPO}_{4}-6,0 \mathrm{~g} / \mathrm{l} ; \mathrm{KH}_{2} \mathrm{PO}_{4}-2,0 \mathrm{~g} / \mathrm{l} ; \mathrm{L}\right.$-asparagine - 10,0 g / 1; Glycerol - 2,0 g /1; $\mathrm{MgSO}_{4}-7 \mathrm{H}_{2} \mathrm{O}-0,5 \mathrm{~g} / 1$; $\left.\mathrm{CaCl}_{2}-2 \mathrm{H}_{2} \mathrm{O}-0,005 \mathrm{~g} / 1\right) \mathrm{pH} 7.0 \pm 0.3$, under stirring at $150 \mathrm{rpm}$ for 48 hours at $55^{\circ} \mathrm{C}$ (Mahajan et al., 2013). Subsequently the cultures were centrifuged at 12.000 $\mathrm{g}$ for $15 \mathrm{~min}$ and the supernatant used for quantification of the activity and evaluation of extracellular L-asparaginase production.

\section{Extracellular L-asparaginase activity}

To confirm the production of extracellular L-asparaginase, the cultures were then filtered and the proteins precipitated in 1:10 (w/w\%) acetone. The resulting proteins were transferred into tubes containing $1.0 \mathrm{~mL}$ of L-asparagine solution $(100 \mathrm{mM})$ in Tris- $\mathrm{HCl}(50 \mathrm{mM}) \mathrm{pH}$ 7.0. The mixture was incubated in a water bath for 30 minutes and the secretion of extracellular LA evaluated by thin layer chromatography (TLC) using silica gel plates, using standards aspartate, asparagine and mix (asparagine + aspartate) (Hendriksen et al., 2009).

\section{L-asparaginase assay}

The activity was measured by Direct Nesslerization of using ammonia or the modified method of Mashburn and Wriston (1964). The enzyme assay mixture consisted of $100 \mu \mathrm{L}$-asparagine $(189 \mathrm{mmol} / \mathrm{L})$ in Tris- $\mathrm{HCl}$ buffer $(\mathrm{pH} 8.6)$ and $100 \mu \mathrm{l}$ crude enzyme extract. The reaction the mixture was incubated at $37^{\circ} \mathrm{C}$ for $30 \mathrm{~min}$ and the interposed by the addition of $100 \mu \mathrm{l}$ of $15 \%$ trichloroacetic acid (TCA). The reaction mixture was centrifuged at $6.000 \mathrm{~g}$ for $5 \mathrm{~min}$ at $4{ }^{\circ} \mathrm{C}$ to remove the precipitates. The ammonia released in the The supernatant was determined by adding $500 \mu \mathrm{l}$ of Nessler reagent to the sample containing $200 \mu \mathrm{l}$ of supernatant and $4.3 \mathrm{ml}$ of distilled water. The samples were centrifuged and incubated at room temperature for $10 \mathrm{~min}$., OD was measured at $396 \mathrm{~nm}$ against blanks that received TCA prior to the addition of crude enzyme. The ammonia produced in the reaction was determined on the basis of in the standard curve obtained with ammonium sulphate. One Unit of L-asparaginase is the amount of enzyme which liberates $1 \mu \mathrm{mol}$ of ammonia in 1 minute at $37^{\circ} \mathrm{C}$.

\section{RESULTS AND DISCUSSION}

In Czapek Dox medium containing different indicators it was possible to verify that six of the sixty-nine isolates had the capacity to produce L-asparaginase. It was possible to easily verify the presence of halo hydrolysis in the medium containing the indicators red phenol, bromocresol purple and neutral red, having better visualization using red indicators of phenol and bromocresol purple (Figure 1 and Table 1). In the detection of halotolerant L-asparaginase in medium containing phenol red indicator it was possible to verify the presence of halos up to the maximum limit of $1.0 \mathrm{M} \mathrm{NaCl}$ (Figure 2 and Table 2).

Although several microorganisms have the ability to produce L-asparaginase with application in tumor therapy, the main sources of the enzyme for therapeutic use are E. coli and E. carotovora, requiring further studies are needed to obtain new microorganisms producing this type with new biochemical characteristics (Godfrin and Bertrand, 2006). Therefore, to optimize the actual therapy, the search for new L-asparaginase with chemotherapeutic agents is urgently needed (Husain et al., 2016). The screening step is necessary for the discovery of new microorganisms capable of producing L-asparaginase with novel characteristics, and several studies are being carried out in order to demonstrate and find bacterial isolates with L-asparaginase production capacity. Thirunavukkarasu et al. (2011) in fungal screening in association with green algae, obtained 84 isolates of which 64 were positive for L-asparaginase production. Izadpanah Qeshmi et al. (2014) in the screening obtained 12 bacterial isolates from promising L-asparaginase-producing marine sediments. 


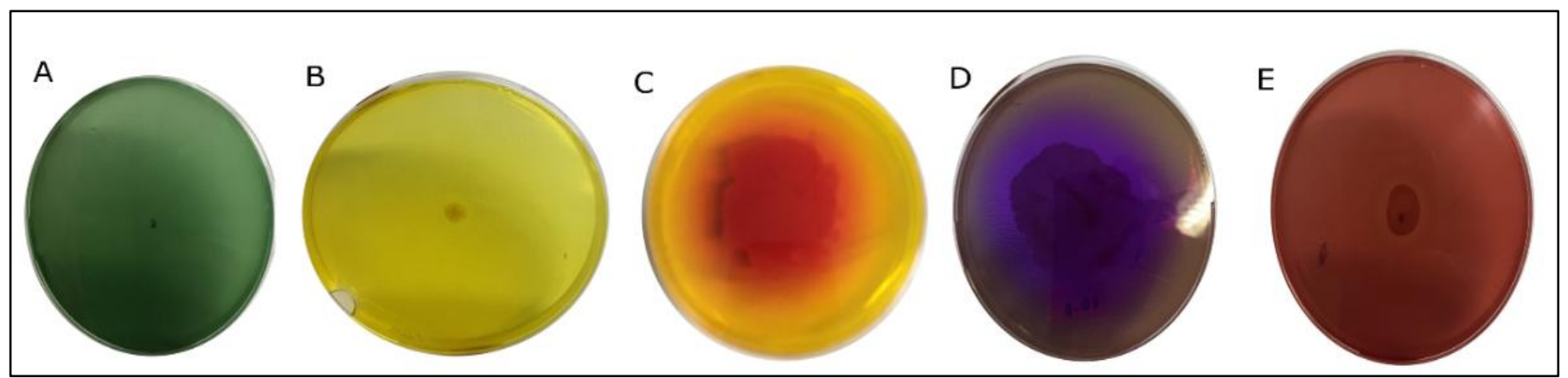

Figure 1. Screening of L-asparaginase by bacterial isolates using the Czapek Dox agar and different indicators.

Legend: Halos around bacterial colonies are indicative of L-asparagine hydrolysis; Indicators: (A) Bromocresol Green; (B) Bromothymol Blue; (C) Phenol Red; (D) Bromocresol Purple; (E) Neutral Red.

Table 1. Screening of L-asparaginase by bacterial isolates using different indicators.

\begin{tabular}{|c|c|c|c|c|c|}
\hline Isolated & Bromocresol Green & Bromothymol Blue & Phenol Red & Bromocresol Purple & Neutral Red \\
\hline SR22 & - & - & + & + & + \\
\hline SR41 & - & - & + & + & + \\
\hline SR44 & - & - & + & + & + \\
\hline SR60 & - & - & ++ & ++ & + \\
\hline SR61 & - & - & + & + & - \\
\hline SS03 & - & - & ++ & ++ & + \\
\hline
\end{tabular}

Legend: (-), Non observable zone; (+) positive with halo less than $3 \mathrm{~cm}$; (++) positive with halo greater than $3 \mathrm{~cm}$.

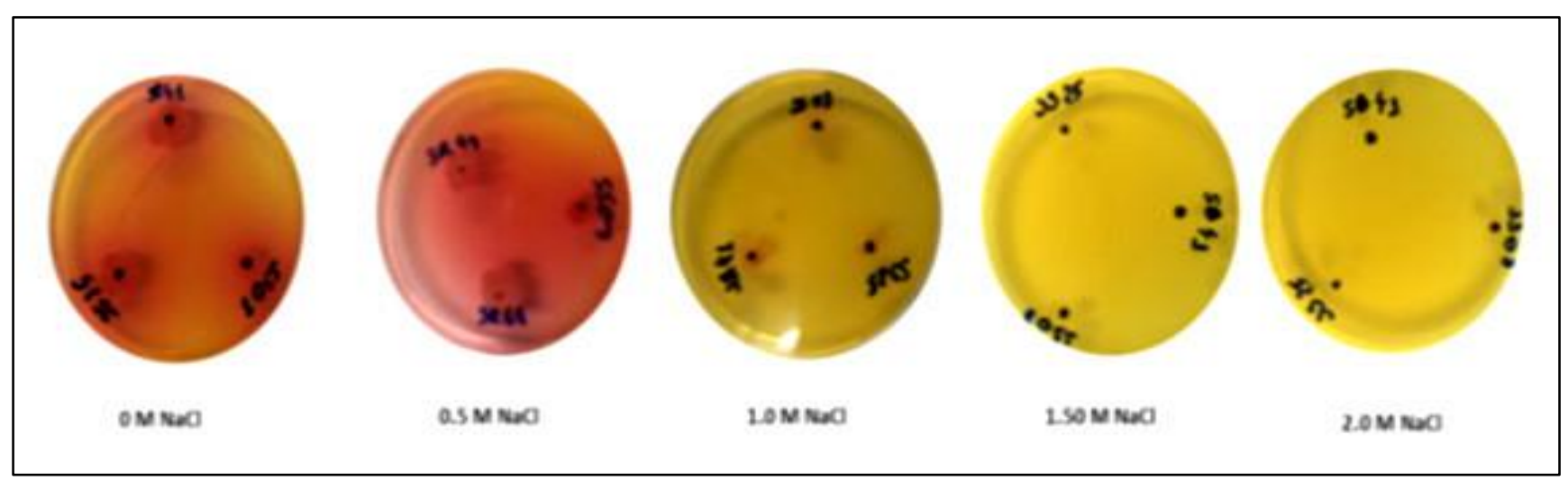

Figure 2. Screening of L-asparaginase by bacterial isolates using Czapek Dox agar with red phenol indicator at different molarities of NaCl.

Legend: Halos around bacterial colonies are indicative of L-asparagine hydrolysis.

Table 2. Qualitative screening production of L-asparaginase culture in different $\mathrm{NaCl}$ molarities.

\begin{tabular}{|c|c|c|c|c|c|c|}
\hline Molarity NaCl & SR22 & SR41 & SR44 & SR60 & SR61 & SS03 \\
\hline $0 \mathrm{M}$ & + & + & + & ++ & + & + \\
\hline $0.50 \mathrm{M}$ & + & + & + & + & + & + \\
\hline $1.0 \mathrm{M}$ & + & + & - & - & + & - \\
\hline $1.5 \mathrm{M}$ & - & - & - & - & - & - \\
\hline $2.0 \mathrm{M}$ & - & - & - & - \\
\hline
\end{tabular}

Legend: (-), Non observable zone; (+) positive with halo less than $3 \mathrm{~cm}$; (++) positive with halo greater than $3 \mathrm{~cm}$.

Several studies indicate that the use of some indicators may mask the production capacity of L-asparaginase in bacterial screening. Mahajan et al. (2013) states that made screening using red phenol indicator reported that this methodology would not be one of the most sensitive methods for detecting activity because the contrast zone obtained (between yellow and pink) is not very marked and distinct, and that the use of another indicator such as bromothymol blue would be more accurate, a fact not seen in this study. However, according to the obtained data it is possible to state that the use of the bromocresol purple indicator shows clearer results in the screening of LA-producing microorganisms.

The morphophysiological data showed that the six isolates producing L-asparaginase are Gram-positive spore-forming bacilli, facultative anaerobe, catalasepositive; it was negative for indole, $\mathrm{H}_{2} \mathrm{~S}$ production and citrate utilization bacterium (Table 3). Those findings led us to consider the isolate belonging to the genus Bacillus which was posteriorly confirmed by the phylogenetic analysis which revealed that the formed a clade with Bacillus subtilis (Figure 3 ). The nucleotide sequence was deposited in GenBank under accession numbers MH698454, MH700655, MH698455, MH700947, MH700752, MH700955, MH701772.

Table 3. Morphological and biochemical characteristics of L-asparaginase-producing isolates.

\begin{tabular}{|c|c|c|c|c|c|c|}
\hline Characteristics & SR22 & SR41 & SR44 & SR60 & SR61 & SS03 \\
\hline Gram staining & + & + & + & + & + & + \\
\hline Morphology & Bacillus & Bacillus & Bacillus & Bacillus & Bacillus & Bacillus \\
\hline Arrangement & - & - & - & - & - & - \\
\hline Endospore & + & + & + & + & + & + \\
\hline Catalase & + & + & + & + & + & + \\
\hline
\end{tabular}


Citation: Bruno Oliveira de Veras, et al., Production of Antileukemic Enzyme L-asparaginase from Marine Bacteria Associated with Coral Siderastrea stellate (Verrill, 1868), Brazil, Australian Journal of Basic and Applied Sciences. 12(11): 87-91. DOI: 10.22587/ajbas.2018.12.11.8

\begin{tabular}{|c|c|c|c|c|c|c|}
\hline Urease & - & - & N.D. & - & - & - \\
\hline Citrate Utilization & - & - & - & - & - & - \\
\hline $\mathrm{H}_{2}$ S Production & N.D. & - & - & - & N.D. & - \\
\hline Indole Production & - & - & - & - & - & - \\
\hline
\end{tabular}

Legend: (-), Negative; (+) Positive (N.D.) Not determined.

Figure 3. Phylogenetic tree of isolated species producing L-asparaginase and other related species based on 16S rRNA sequences. The scale bar represents 0.01 substitutions per site. GenBank accession numbers of the sequences are given in parentheses.

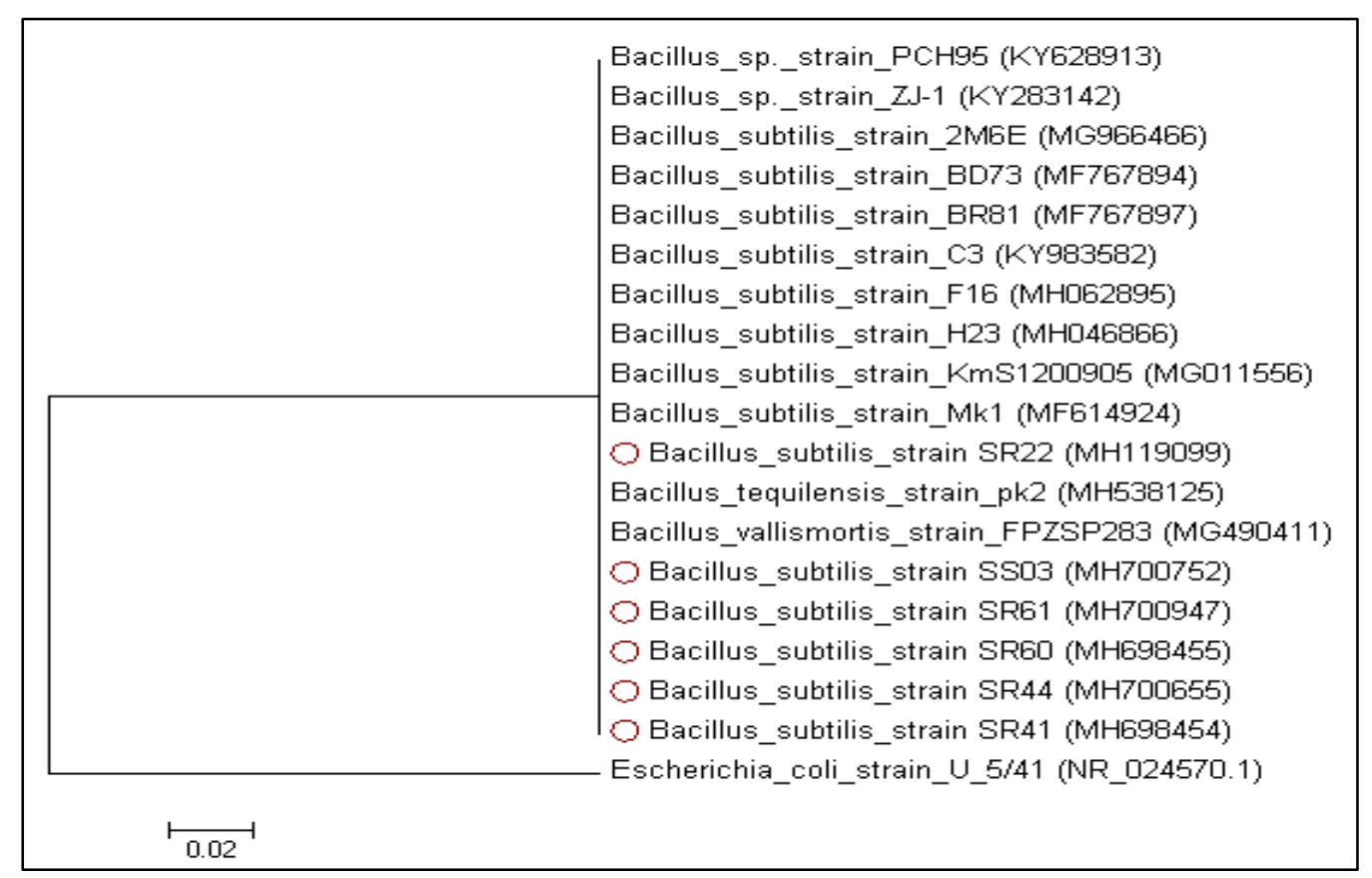

Previous studies related the L-asparaginase production of Bacillus subtilis collected from India. Despite the isolate Bacillus subtilis strain hswx88 showed the enzymatic activity (23.8 UI/mL) 1.7 and 14.5 times higher than the reference organisms (Pectobacterium carotovorum MTTC1428 and Bacillus sp. BCCS 034) (Pradhan et al., 2013), the enzymatic activity of the isolates found in the present study was even higher, with values ranging from 139,6 to 300,5 UI/mL. The isolate SR22 showed the highest value, emphasizing the great potential of enzyme production from this strain (Table 4).

Table 4. Quantitative screening production of L-asparaginase for isolated bacterial.

\begin{tabular}{|c|c|}
\hline Isolated & Total activity (IU/mL) \\
\hline SR22 & $300,5 \pm 3,83$ \\
\hline SR41 & $222,8 \pm 3,59$ \\
\hline SR44 & $280,5 \pm 4,06$ \\
\hline SR60 & $139,6 \pm 4,93$ \\
\hline SR61 & $231,4 \pm 3,57$ \\
\hline SS03 & $170,0 \pm 5,70$ \\
\hline
\end{tabular}

Aiming to confirm the production of extracellular L-asparaginase, the isolates were evaluated by TLC and this production was confirmed (Figure 4), sincethe amino acid L-asparagine was consumed in all of the samples, demonstrating that this substrate was used by the produced enzyme. The extracellular production is considered advantageous over the intracellular type because of the higher production of soluble bioactive proteins, easy extraction and relatively free from endotoxins, minimizing the possible adverse reactions. Extracellularproteins exported to the medium are probably more soluble, bioactive and relatively free from endotoxins. The extracellular enzymes are also related to have the proper folding, specially that requiring disulfide bridge formation, resulting in interesting enzymes for the development of new drugs (Pradhan et al., 2013).

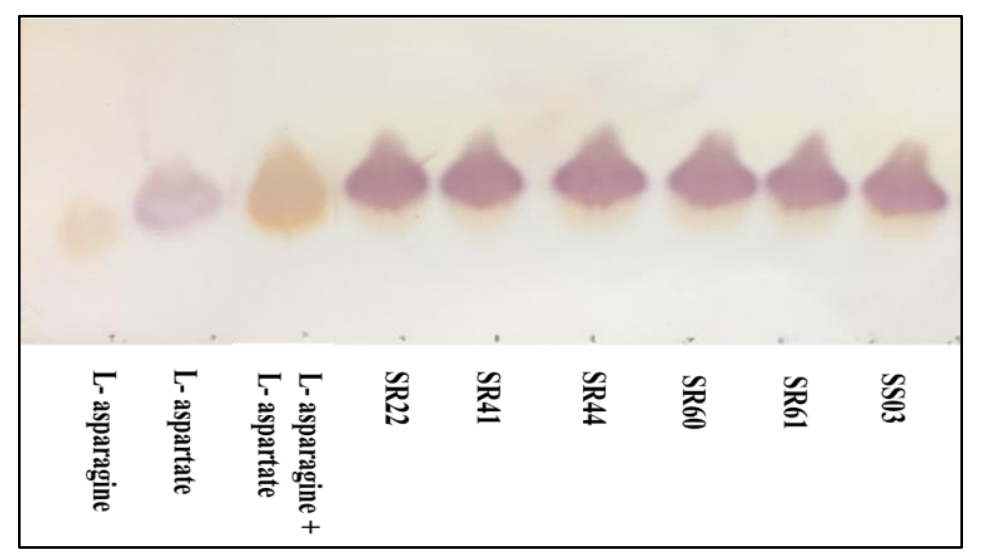

Figure 4. Thin-layer chromatography (CCD) for L-asparaginase activity by bacterial isolates. 


\section{CONCLUSIONS}

The bacteria obtained from the Siderastrea stellata coral have potential being capable of producing L-asparaginase with thermostable and halotolerant properties. More detailed and further studies are still needed to optimize culture conditions in order to obtain a high production of L-asparaginase among the analyzed isolates. In addition, the intrinsic characteristics of the isolates can be used in recombinant DNA technology.

\section{ACKNOWLEDGEMENT}

This work was supported by the Brazilian funding agencies CNPq and CAPES.

\section{CONFLICT OF INTEREST}

Authors declare that there is no conflict of interest.

\section{REFERENCES}

Alqasim A. M. Z, Al-Hadith R. H., Al-Khalid A. N. 2018. Coagulopathic side effect of L-asparaginase on fibrinogen level in childhood acute lymphoblastic leukemia during induction phase. Hematol. Oncol. Stem Cell Ther., S1658-3876(18)30006-2.

Campbell H. A., Mashburn, L. T., Boyse E. A., Old L. J. Two L-asparaginases from Escherichia coli their separation, purification, and antitumor activity. Biochemistry. 6(3):721-730.

Chen S.-H. 2014. Asparaginase Therapy in Pediatric Acute Lymphoblastic Leukemia: A Focus on the Mode of Drug Resistance. Pediatr. Neonatol. 1-7. Cocco C., Airoldi I. 2011. Cytokines and microRNA in pediatric B-acute lymphoblastic leukemia. Cytokine Growth Factor Rev. 22(3)149-156.

Dumorne K; Cordova D. C.; Astorga-Elo M.; Renganathan P.2017. Extremozymes: A Potential Source for Industrial Applications. J. Microbiol. Biotechnol. 27(4): 649-659.

Dustan P. 1973. Distribution of zooxanthellae and photosynthetic chloroplast pigments of the reef-building coral Montastrea. Bull. Mar. Sci. 29(1):79-95. Gallagher M. P., Marshall R. D., Wilson, R. 1989. Asparaginase as a drug for treatment of acute lymphoblastic leukaemia. Essays Biochem. ,24:1-40. Godfrin Y., Bertrand Y .2006. L-asparaginase Introduced into Erythrocytes for the Treatment of Leukaemia (ALL). BioMedES. 1(1): 10-13.

Hendriksen H.V., Kornbrust B.A., Østergaard P.R., Stringer M.A. 2009. Evaluating the potential for enzymatic acrylamide mitigation in a range of food products using an asparaginase from Aspergillus oryzae. Journal of Agricultural and Food Chemistry. 57(10):4168-4176.

Hendriksen H.V., Kornbrust B.A., Østergaard P.R., Stringer M.A. 2009. Evaluating the potential for enzymatic acrylamide mitigation in a range of food products using an asparaginase from Aspergillus oryzae. Journal of Agricultural and Food Chemistry. 57(10):4168-4176.

Hirunavukkarasu N., Suryanarayanan T. S., Mural T. S.i, Ravishankar J. P., Gummad S. N. 2011. L-asparaginase from marine derived fungal endophytes of seaweeds. Mycosphere. (2), pp. 147-155.

Hu Y. et al., 2015. Statistical research on the bioactivity of new marine natural products discovered during the 28 years from 1985 to 2012. Mar. Drugs.13(1):202-21.

Husain I., Sharma A., Kumar S., Malik F. 2016. Purification and Characterization of Glutaminase Free Asparaginase from Enterobacter cloacae: In-Vitro Evaluation of Cytotoxic Potential against Human Myeloid Leukemia HL-60 Cells. PLoS ONE. 11(2): e 0148877.

Izadpanah Qeshmi F., Javadpour S., Malekzadeh, K., Tamadoni Jahromi S., Rahimzadeh M. 2018. Persian Gulf is a Bioresource of Potent LAsparaginase Producing Bacteria: Isolation \&amp; Molecular Differentiating, Int. J. Environ. Res.8 (3): 813-818.

Mahajan R. V., Saran S., Saxena R. K., Srivastava A.K. 2013. A rapid, efficient and sensitive plate assay for detection and screening of 1-asparaginaseproducing microorganisms. FEMS Microbiol. Lett.341(2)1:22-126.

Michalska K., Jaskolski M. Structural aspects of L-asparaginases, their friends and relations. Acta Biochim. Pol., vol. 53, no. 4, pp. 627-40, 2006.

Narta U. K., Kanwar S. S., Azm W.,20007. Pharmacological and clinical evaluation of 1-asparaginase in the treatment of leukemia. Crit. Rev. Oncol. Hematol. 61(3): 208-221.

Prabhu R. H., Bhise K. S., Patravale V. B. 2017. Marine Enzymes in Cancer,” in Advances in food and nutrition research. 80:1-14.

Prihanto A. A, Wakayama M. 2016. Marine Microorganism in Advances in food and nutrition research. 79: 1-25.

Shrivastava A., Khan A. A., Khurshid M., Kalam M. A., Jain S. K, Singhal P. K. 2015. Recent developments in 1-asparaginase discovery and its potential as anticancer agent. Crit. Rev. Oncol. Hematol., 1-12.

Srivastava A. et al. 2018.Screening of biologically active microbial strains having therapeutic applications. Indian J. Exp. Biol. 56: $244-251$.

Wriston J. C., Yellin T. O. 1973. L-asparaginase: a review Adv. Enzymol. Relat. Areas Mol. Biol. 39: 185-248. 